Магнитно-стрикционный преобразователь закрепляется на суппорте токарного станка, а процесс упрочнения производится по винтовой траектории при включенной подаче перемещения суппорта и вращении наплавленного вала на станке.

Обкатка наплавленных поверхностей гребных валов осуществляется гидравлическим двухроликовым или трехроликовым приспособлением также на токарном станке. Усилие обкатки устанавливают в зависимости от толщины наплавленного слоя и состава наплавленного металла.

После упрочнения ультразвуковой ударной обработкой или обкаткой роликами наплавленный металл должен иметь твердость в пределах 240...320 НВ.

Опыт показывает, что применение описанной технологии ремонта судовых гребных валов обеспечивает их долговечность на уровне новых.

\title{
Строительные материалы для войсковой фортификации
}

\author{
Федюк P.C., к.m.н., \\ Смоляков А.К., студент, \\ Тимохин Р.А., студент, \\ Дальневосточный федеральный университет, \\ 2. Владивосток \\ E-mail: roman44@yandex.ru
}

Научный руководитель: о.т.н., профессор Лесовик В.С.

В современных политических реалиях, поддержание обороноспособности является необходимой задачей. Современные фортификационные сооружения должны удовлетворять требованиям по различным видам защиты (рис. 1).

Рассмотрим исторический аспект развития фортификационных сооружений (опыт Первой и Второй мировых войн). По степени защиты казематированные фортификационные сооружения (огневые, наблюдательные и командные пункты, убежища) разделяются на:

1) легкие, обеспечивающие от пуль и осколков;

2) усиленные - от поражения снарядом 125-мм гаубицы;

3) тяжелые, рассчитанные против прямого попадания снаряда 155-мм гаубицы или 50-кг авиабомбы;

4) мощные, обеспечивающие защиту при прямом попадании снарядов калибра выше 155 мм и авиабомбы весом 100 кг [1, стр. 25].

Толщина монолитных железобетонных стен и потолков зависела от оружия, от которого предполагалось защищаться (в основном артиллерия), для проектирования этих сооружений развивалась отдельная наука [2, стр. 142]. Расчёт составных частей проводился по эмпирическим формулам и сильно зависел от принимаемых условий (скорость, угол падения, форма бомб и снарядов и условия их взрыва; качество и армировка бетона, запас прочности и др.), а потому результаты у разных школ могли отличаться. 


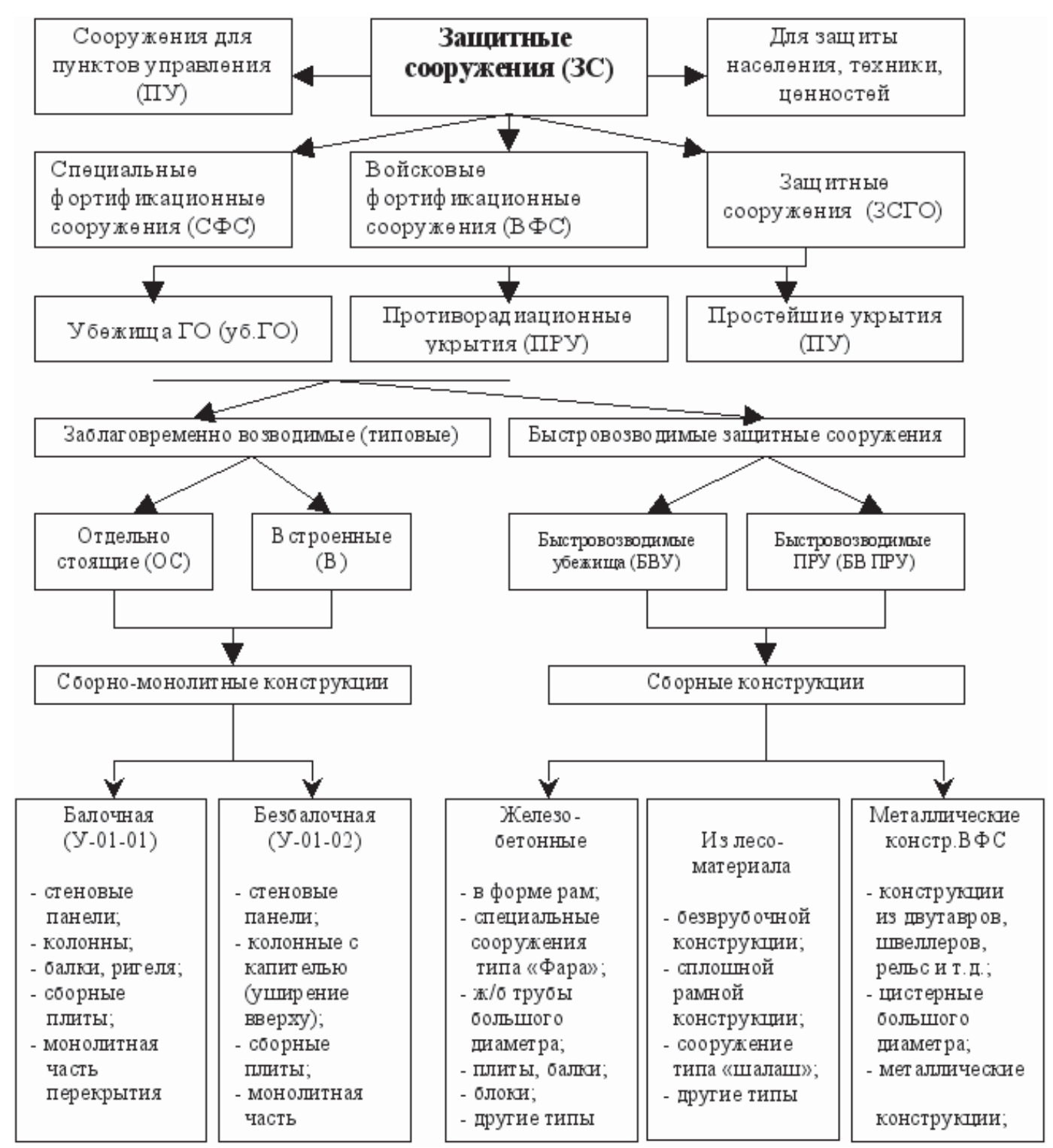

Рис. 1. Строительно-техническая классификация защитных (фортификационных) сооружений

Исходя из опыта Первой мировой войны, инженеры долговременных сооружений в основном обращали внимание на укрепление перекрытий, часто оставляя неоправданно слабые стены. Ближе ко Второй мировой, предвидя новые опасности (противотанковые пушки и фугасные авиабомбы), стали упрочнять стены, добавлять в них противооткольную одежду, совершенствовать амбразуры, а также отказываться от чисто броневых закрытий, оставляя металл танкам.

Современные фортификационные сооружения строятся из высокопрочного бетона.

Высокопрочный бетон - тяжелый или мелкозернистый бетон классов по прочности на сжатие В60 и выше, приготовленный с применением вяжущего на основе портландцемента [3, стр. 66]. Строительство из высокопрочных бетонов позволяет как заказчику, так и строителю не ограничивать себя сложностью архитектурных решений. В сочетании с прочной арматурой он занимает немаловажную роль в современном строительстве, особенно в предварительно напряженных железобетонных конструкциях. 
Сборные конструкции из предварительно напряженного железобетона изготовляют преимущественно из тяжелых бетонов марок 400 - 500. Использование бетонов более высоких марок позволяет снизить собственный вес конструкций, уменьшить площадь их сечения, создать более рациональные конструктивные формы элементов.

Высокопрочный бетон, обладающий повышенной скоростью твердения, набирает прочность в сравнительно короткие сроки. По этой причине можно сократить продолжительность пропаривания изделий из таких бетонов при заводском изготовлении, а в некоторых случаях отказаться от тепловлажностной обработки. Пониженная деформативность высокопрочного бетона под кратковременной и длительной нагрузками улучшает жесткость элементов конструкции и позволяет уменьшить потери предварительного натяжения от ползучести бетона. Усадка высокопрочного бетона, как правило, не превышает в сопоставимых условиях аналогичных деформаций бетона обычной прочности.

Ю.М. Баженов относит к высокопрочным бетоны с прочностью 50-100 МПа и к особо высокопрочным с прочностью выше 100 МПа [4, стр. 214]. Для сравнения можно привести некоторые значения теоретической прочности цементного камня по мнению отечественных и зарубежных исследователей. В частности, по И.Н. Ахвердову, теоретическая прочность цементного камня при нулевой пористости составляет 1370 МПа. По данным А.М. Невилля [5, стр. 127], теоретическая прочность цементного камня составляет 10500 МПа.

Известно, что теоретическая прочность бетона гораздо выше практической, то есть использование потенциальных возможностей бетона еще невелико. Это связано с тем, что нет единого мнения о структуре бетона, его поведении под нагрузкой до образования микротрещин, нет четкого представления о прочности бетона, ее физических свойствах, о критериях оценки теоретической прочности и разрушительного процесса, о путях снижения дефектности структуры бетона, отсутствуют достаточные знания о сопротивлении бетона разрушению от совместного действия нагрузки и окружающей среды и многом другом

Разработка высокопрочных бетонов началось еще в XX в. В частности, в 60-70 гг. научная школа под руководством О.Я. Берга, установила, что прочность бетона зависит, в основном, от водоцементного отношения бетонной смеси и от активности портландцемента. Ю.М. Баженов к этому добавляет высокий предельно допустимый расход цемента; применение суперпластификаторов и комплексных добавок; особо тщательное перемешивание и уплотнение бетонной смеси; создание наиболее благоприятных условий твердения [4, стр. 215].

А.Н. Марков, Н.В. Михайлов, П.А. Ребиндер принимали, что прочность цементного камня можно считать по прочности кристаллического сростка с имеющимися в нем порами. Ученые из Харьковского Промстрой НИИ проекта вывели, что, прочность цементного камня является линейной функцией от химически связанной воды.

Согласно современным представлениям, для высокопрочных бетонов следует принимать цементы активностью Rц>50 МПа, желательно с низкими значениями нормальной густоты. 
Предел прочности крупного заполнителя должен быть на 20\% выше предела прочности проектируемого бетона. Для особо высокопрочных бетонов применяют заполнители из диабаза, базальта и других прочных горных пород [6-9].

Для гарантированного плотной и прочной структуры бетона, расход цемента ограничивают: для сборных ж/б изделий малых и средних размеров расход цемента

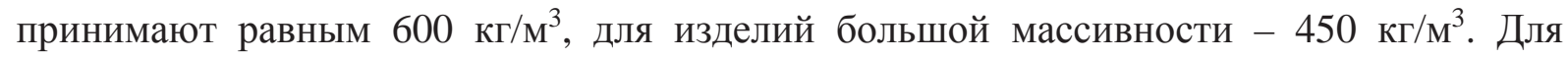
снижения расхода цемента используют:

1. Применение более высокопрочного цемента и его механохимическая активация.

2. Применение смеси заполнителей с минимальной водопотребностью и пустотностью.

3. Введение суперпластификаторов и комплексных добавок.

4. Назначение класса бетона по его прочности после 28 сут.

Наилучшими условиями для твердения высокопрочного бетона являются нормальные $\left(20-25^{\circ} \mathrm{C}, 100 \%\right.$ влажность).

При соблюдении рассмотренных условий, прочность бетона может превысить марку цемента в 1,5-1,7 раза. А применение композиционных вяжущих, подвергнутых механохимической активации, позволит получать бетоны прочностью выше 100 МПа.

В то же время, как уже было отмечено ранее, потенциал теоретической прочности бетона раскрывается лишь на 0,07-2,5\%. Есть сведения [10, стр. 311] о том, что в США получен бетон обладающий прочностью на сжатие через 28 сут. - 668 МПа при пористости 2-5\%. При пористости 10-15\% материал имеет прочность 281-352 МПа. За рубежом достигнута прочность тяжелого бетона 460 МПа при твердении его под давлением $345 \mathrm{MПа} \mathrm{и} \mathrm{температуре} 150^{\circ} \mathrm{C}$. В США, Финляндии и Норвегии получены бетоны с прочностью до 250 МПа, а в промышленных условиях до 170 МПа [11, стр. 73].

Список литературы:

1. Борисов Ф.В., Джусь С.И. Основы применения и размещения на местности казематированных фортификационных сооружений. - М: ИЗДАНИЕ ВИА, 1942.

2. Лепескин Н.А., Образцов В.В., Федюк Р.С. Исследование проницаемости мелкозернистого бетона на композиционном вяжущем // В сборнике: Интеллектуальные строительные композиты для зеленого строительства: Международная научно-практическая конференция, посвященная 70-летию заслуженного деятеля науки РФ, члена-корреспондента РААСН, доктора технических наук, профессора Валерия Станиславовича Лесовика. 2016. С. 141-146.

3. Лесовик В.С., Федюк Р.С. Теоретические предпосылки создания композитов повышенной непроницаемости // Вестник Сибирской государственной автомобильнодорожной академии. 2016. № 1 (47). С. 65-72.

4. Баженов Ю.М. Технология бетона. - М.: Высшая школа, 1987. - 414 с.

5. Невилль А.М. Свойства бетона (перевод с английского). - М.: Стройиздат, 1972. $-344 \mathrm{c}$.

6. Лесовик В.С., Урханова Л.А., Федюк Р.С. Вопросы повышения непроницаемости фибробетона на композиционном вяжущем // Вестник ВСГУТУ. 2016. № 1. C. 5-10. 
7. Fediuk R.S., Yushin A.M. The use of fly ash the thermal power plants in the construction // B сборнике: IOP Conference Series: Materials Science and Engineering 21st International Conference for Students and Young Scientists. 2015.

8. Смоляков А.К., Федюк Р.С. Исследование влажностного режима Приморского края с позиции влияния на строительные конструкции // В сборнике: Безопасность строительного фонда России. Проблемы и решения Материалы Международных академических чтений. Курский государственный университет. 2015. С. 103-108.

9. Fediuk R.S., Khramov D.A. Physical equipment spectroscopic study of coal ash // Современное строительство и архитектура. 2016. № 1 (01). С. 57-60.

10. Шейкин А.Е. Структура и свойства цементных бетонов. - М.: Стройиздат, 1979. - 344 c.

11. Федюк Р.С. Проектирование цементных композитов повышенной непроницаемости // Вестник МГСУ. 2016. № 5. С. 72-81.

Исследование дозовой нагрузки от радона при отоплении сельских домов природным газом на примере села Немюгюнцы Хангаласского района

Христофорова С.E., аспирант, Институт космофизических исследований и аэрономии им. Ю.Г. Шафера СО РАН, ведущий инженер,

Северо-Восточный федеральный университет, г. Якутск E-mail: sardanaeqorova2606@yandex.ru Наумова К.А., стариий преподаватель, Северо-Восточный федеральный университет, г. Якутск

Научные руководители: д.ф.-м.н., доцент Степанов В.E., к.ф.-м.н., доцент Тимофеев В.Е.

Известно, что уран распределен в основном в земной коре и сопровождает углеводородные месторождения, а именно каменный уголь, сланцы, нефть и природный газ. В литературе имеются указания на то, что радон выделяется из природного газа, но нет систематических исследований по измерению радона при отоплении природным газом одноэтажных жилых помещений.

Измерения объемных активностей радона проводились в одноэтажных деревянных домах с газовым отоплением в селе Немюгюнцы, Хангаласского улуса, Республики Саха (Якутия). Эксперимент проводился в жилых домах, использующих котлы типа: КЧМ, АОГВ, КСГ и немецкого Wolf.

В этой статье представлены результаты долговременных измерений объемной активности (ОА) радона в жилых домах с газовым отоплением и расчеты ЭРОА радона для средних значений измерений. Работы велись с помощью немецкого прибора радиометра Alpha Guard PQ2000 [3, стр.326].

ЭРОА радона для неравновесной смеси короткоживущих дочерних продуктов распада в воздухе называется объемная активность радона, находящегося в равновесии 